\title{
The Length of Awakening Time from Hibernation of Three Species of Bats
}

DEUGOSC CZASU BUDZENIA SIE $\mathrm{Z}$ HIBERNACJI TRZECH GATUNKOW NIETOPERZY

\section{Wincenty HARMATA}

\begin{abstract}
Harmata W., 1985: The length of awakening time from hibernation of three species of bats. Acta theriol., 30, 20: 321-323 [With 2 Figs.]

The time of awakening from winter sleep has been studied in three species of bats: Rhinolophus hipposideros, Myotis myotis and Plecotus auritus under natural conditions. Seasonal changes in the time of awakening have been found in bats $R$. hipposideros wintering in constant thermal conditions. In autumn (October) and in spring (April) the time was shorter than that observed in the middle of the winter sleep (January).

[Dept. Psychol. \& Ethol. Anim., Jagiellonian Univ. M. Karasia 6, 30-060 Kraków, Poland]
\end{abstract}

\section{INTRODUCTION}

Several species of hibernating bats can arise from a torpid state in winter couple of times entering the winter sleep again after a short time (Verschuren, 1949). However most of the detailed studies on thewinter awakening time have dealt with bats under laboratory conditions (Eisentraut, 1937; Elliasen, 1955, Jánský \& Hájek, 1961; Hughes, 1968; Brenner, 1974). The purpose of this study was to determine the length awakening time from hibernation of three species of bats in natural conditions in different thermal conditions and to note aspects of their behaviour during this process.

\section{METHODS}

The research was carried out in the certain types of winter hiding places, natural and artificial caves, cellars and underground palssages in vicinity of Cracov town $\left(50^{\circ} 04^{\prime} \mathrm{N}, 19^{\circ} 57^{\prime} \mathrm{E}\right)$, from 1961 to 1964 and from 1978 to 1983. Bats were forced to awake once by taking the specimen from the site of winter sleepto other place, with the time taken till the full awakening and flaying out. The awakening time from hibernation were measured in minutes to first flight.

\section{RESULTS AND DISCUSSION}

The average time in Rhinolophus hipposideros (Bechstein, 1800) (139. observations) measured since awakening till the moment it is able to fly is $52 \mathrm{~min}$. at $5.5^{\circ} \mathrm{C}$ and $26 \mathrm{~min}$. at $9.5^{\circ} \mathrm{C}$ (Fig. 1). In Myotis myotis (Borkhausen, 1797) (71 observations) this time is $49 \mathrm{~min}$. at $3.5^{\circ} \mathrm{C}$ but $30 \mathrm{~min}$. at $8.5^{\circ} \mathrm{C}$, whereas in Plecotus auritus (Linnaeus, 1758) (18 observations) it is $38 \mathrm{~min}$. at $3.5^{\circ} \mathrm{C}$ but $24 \mathrm{~min}$. at $9.0^{\circ} \mathrm{C}$. The data show that. time of awakening from hibernation is shortest in $P$. auritus at high 
temperature that corresponds to the ethology and ecology of hibernation of these species. In all three species studied the time of awakening from hibernation depends on air temperature in winter habitat, body temperature and thermopreferendum (Harmata, 1969, 1973).

There were found some changes in length of awakening time in different periods of hibernation in $R$. hipposideros. 79 observations were gathered in one of the natural cave (The Ciemna Cave) in winter 1979/1980 where the annual air temperature was nearly constant (changing only from 6 to $7^{\circ} \mathrm{C}$ ) while humidity oscilated from 90 to $100 \%$. It was found that the shortest time of awakening of both male and female bats was observed

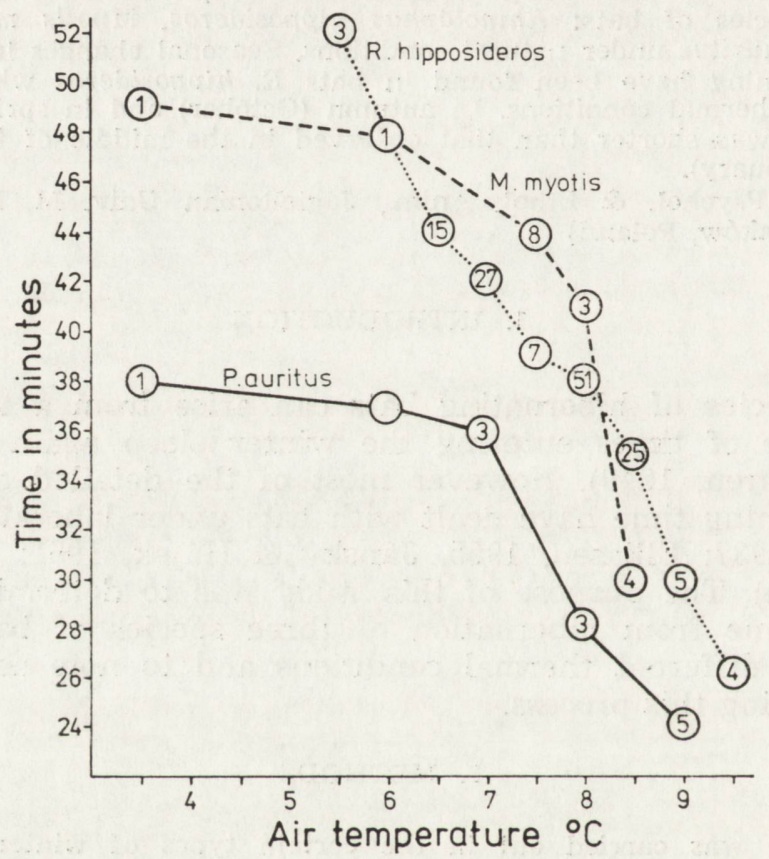

Fig. 1. The length of the awakening time (in minutes) in three species of bats in different temperatures. Number of observations are given in the circles on the diagram.

at the beginning of hibernation in October (mean average is $27.23 \pm 1.5$ min.) and the longest one was in January when the hibernation was deepest (mean average $47.11 \pm 1.1 \mathrm{~min}$.). The awakening time at the end of hibernation, i.e. in April was $40.23 \pm 0.7 \mathrm{~min}$. (Fig. 2). Seasonal changes in awakening time in $M$. myotis and $P$. auritus cannot be studied because of small number of observations.

The short awakening time in autumn is caused by the fact, that bats can quite often fly out from caves in that period. The longest time in spring resulted from debility after the hibernation period and great difficulties in hunting because of bad weather conditions. It seems that quickness of awakening of bats from hibernation indicaties how deep the hibernation is. 


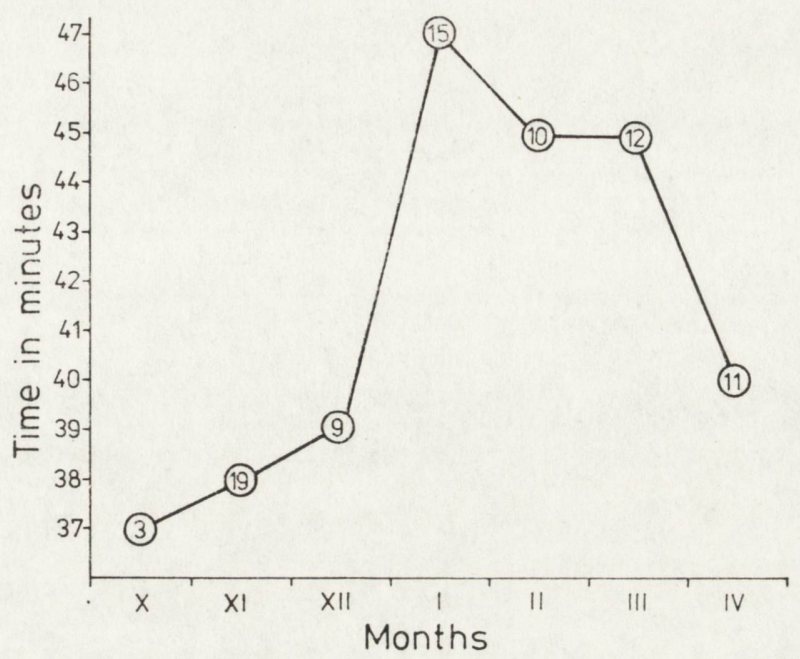

Fig. 2. The length of the awakening time (in minutes) from hibernation in the Rhinolophus hipposideros in different months. Number of observations are given in the circles on the diagram.

Results of investigations presented above remain in a good agreement with relevant data for $M$. myotis observed in artificial conditions (Eisentraut, 1937; Jánský \& Hájek, 1861.

\section{REFERENCES}

Brenner F. J., 1974: Body temperature and arousal rates of two species of bats. Ohio J. Sci., 74: 296-300. - Elliasen E., 1955: The temperature rise electrocardiogram and electro-encephalogram of the hibernation bats during the awakening process. Natuurvitenskapeling rekke, 6: 1-23. - Eisentraut M., 1937: Die deutschen Fledermause. Eine biologische Studie. Leipzig Schöps: 1-184. Leipzig. - Harmata W., 1969: The termopreferendum of some species of bats (Chiroptera). Acta theriol., 14: 49-62. - Harmata W., 1973: The termopreferendum of some species of bats (Chiroptera) in natural conditions. Zesz. Nauk. UJ, 19: 127-141. - Hughes S. E. 1968: Temperature of the bats, Plecotus townsendii during arousal. J. Mammal, 49: 140-142. - Jánský J. \& Hájek L., 1961: Thermogenesis of the bats, Myotis myotis Borkh., Physiol. Bohemosl., 10: 283-289. - Verschuren J., 1949: L'activité et les déplacements hivernaux des Chéiropterès en Belgique. Bull. Mus. roy. Hist. Nat. Belg., 25: 1-7.

Accepted, February 18, 1985. 